HRM Strategies and MNCs from Emerging Economies in the UK

Yi Ying Chang, Adrian J. Wilkinson*, Kamel Mellahi

* Address for Correspondence

\author{
Professor A. J. Wilkinson \\ Griffith Business School \\ Griffith University
}

Nathan

4111

Qld

Australia 


\section{HRM Strategies and MNCs from Emerging Economies in the UK}

Purpose:

HRM practices in foreign subsidiaries have been the subject of much attention in recent years. However, research on HRM practices by subsidiaries of multinationals has so far focused largely on subsidiaries of western multinationals in western and or emerging economies. We have little knowledge concerning HRM practices of subsidiaries of multinationals from emerging economies in developed western countries.

Method: survey

Findings:

A blend of practices has been adopted by the subsidiaries, ranging from emulating home country practices, adapting host country practices, and a melange of home and host country practices.

Value:

First, we have identified HRM practices used by emerging economy MNCs in an advanced economy. Second, our results suggest that MNCs from emerging economies behave differently from MNCs from developed countries such as Japan, US and Western European countries. Past research shows that MNCs from advanced economies such as Japanese MNCs in the UK tend to transplant the ideas and practices of so-called excellent human resource management systemsfrom their own parent companies . However, Taiwanese MNCs deliberately adopt a varied HR approach to operate in an advanced economy as a result of dual pressures of home and host country effect. Consequently, apart from strategic issues wholly made by HQ in Taiwan, other HR practices either adapt to local practices or use a hybrid style. 
Keywords Multinationals; Multiple HRM Strategies and Practices; Taiwan;

UK; Emerging economies; Developed countries. 


\section{Introduction}

Over recent years, there has been a growing body of research on the impact of home and host country effects on HRM practices of subsidiaries of Multinationals (MNCs) (Ferner, 1997; Gamble, 2003; Farley et al., 2004). The main limitation of the current body of research is the exclusive focus on western multinationals in western countries or emerging economies (Almond et al., 2003; Edwards, 1998; Edwards and Ferner, 2004; Farley et al., 2004; Ferner and Quintanilla, 1998; Ferner and Varul, 1999; Guest and Hoque, 1996; Innes and Morris, 1995; Muller, 1998; Tayeb, 1998). Extant research has not examined HRM practices of MNCs from emerging economies operating in Western developed countries. This research will help fill this gap.

This research is important for at least two reasons. First, more MNCs from emerging economies are entering western countries (Liu et al., 2005). For instance, there are five of Taiwan's MNCs in the top 50 of the non-financial MNCs from the emerging economies (UN World Investment Report, 2003). The increasing presence of Taiwan investment and subsidiaries in the UK has resulted in the hiring of more than 9,000 employees and managers (FAME, 2004). Designing and emerging effective HRM policies to manage these local work forces poses several challenges. For example, the recent high profile takeovers of Siemens’ mobile production site in Germany by Benq Group—a Taiwanese company—raised several questions: Will Benq use a German or Taiwanese style of management? And how will workers in Germany react to Taiwanese management practices? Second, this paper expands our understanding of what we know about the impact of host country and home country effect on HRM strategies and 
practices in this new socio-cultural setting. Questions still remain on the generalisability of findings on home and host country effects from the studies conducted on western MNCs. MNCs from emerging economies may want to emulate host country practices in western countries rather than implement home country practices. Thus, this research is designed to extend an already-documented phenomenon in a new setting.

Previous research on MNCs had identified dual pressures for the need to conform to home country (push force) and host country (pull force) institutional environments when adoptiing HRM strategies and practices (e.g.Rosenzweig and Nohria, 1994; Taylor et al., 1996; Farley et al., 2004; Hillman and Wan, 2005). We know very little on how these pressures influence HRM strategies and practices at subsidiary level of MNCs from emerging economies. While previous comparative research on HRM in the Asia Pacific region (Ulgado et al., 1994; Hofstede and Bond, 1988; Hofstede, 1993, 1997; Bae et al., 1998; Chow et al., 1999; Huang, 2000; Awasthi et al., 2001; Chow et al., 2000) has identified the national origin of firms including its national institutions and culture as the key shapers of HRM practices in the region, these studies do not address how cultural and institutional differences affect the dissemination of HRM strategies and practices by MNCs from emerging economies operating in a developed economy. This research will help to clarify this issue.

The organization of our paper is as follows. First, we identify and compare HRM practices in Taiwan and the UK. Second, we describe the research method used to identify HRM practices used by Taiwanese MNCs. Third, we analyse the results of the survey. Last, the paper concludes with a discussion of how our findings relate to existing research and provide suggestions for related future research. 


\section{HRM in Taiwan and the UK: comparisons of past research}

The cultural and institutional environments in Taiwan are different from that of the UK. Namely, Taiwanese culture has been categorised into high in power distance, low in individualism, moderate in uncertainty avoidance and masculinity, and high in long-term orientation (Hofstede, 1980). Taiwanese management culture is rooted in Confucianism: harmony and consensus (the basic tenets of Confucian philosophy-the principle of harmony, or a harmonious attitude, and consensus towards a conflict-free working relation); thrift; protecting 'face'; ordering relationships by status; duty to family; and economic egalitarianism (Huang, 2000). Protecting face is related to harmony in that both emphasize the avoidance of conflict in interpersonal relationships (Wu, 2004). Taiwan's institutional environments also shape HRM practices especially in labour-management relationships (Chen et al., 2003). In the UK, the core concept of HRM is individualism, which is partly due to the "no such thing as society" culture created by many years of Conservative government (Guest, 2001). In order to explore the home and host country effect in the adoption of HRM practices of Taiwanese MNCs in the UK, we use extant literature to identify and compare HRM practices typically used by Taiwanese companies and British counterparts (see table 1).

\section{Recruitment and selection}

British companies appear to use 'recruitment agencies' and 'executive search consultants' more frequently than do the Taiwanese-owned companies for managerial and 
professional vacancies (Hsu and Leat, 2000; CIPD, 2004). With regard to the recruitment process, Taiwanese firms generally target 'friends and relatives' (quanxi) (Hsu and Leat, 2000; Hempel and Chang, 2002). Regarding selection techniques, British firms use 'panel interview', 'aptitude tests', 'competency-based interviews' and 'application forms' more frequently than do the Taiwanese-owned firms (Hsu and Leat, 2000; Kersley et al., 2005).

\section{Training and development}

Taiwanese firms tend to use on-the-job training programmes including professional training to maintain advanced skills among the key employees (Zhu et al., 2000; Zhu, 2003) more then British counterparts (Cully et al., 1999; Faulkner et al., 2002; Kersley et al., 2005). Under the influence of Confucius culture such as 'everyone can potentially be my teacher’, Taiwanese firms not only generally provide specialised technical training within the company for lower-level key members but also offer more general training for potential candidates for top-level posts (Von Glinow et al., 1999).

\section{Pay and benefits}

Under the influence of the Chinese culture that favours 'the middle way', tries to protect the economic security of junior employee, and promotes a caring and supportive to those in the lowest positions, Taiwanese firms are more egalitarian in pay than British firms (Von Glinow et al., 1999). In order to maintain and emphasis harmony in the work place, Taiwanese firms rely more on team and group related pay then on individual performance-related pay. In contrast, British firms focus more on rewards and 
punishments based on individual performance of employees (Von Glinow et al., 1999; Wu, 2004).

\section{Performance appraisal system}

Performance appraisals vary widely between Taiwanese companies and their British counterparts (Wu, 2004). Taiwanese companies focus less on objective, quantifiable results than do their British equivalents. Additionally, Taiwanese firms are more reluctant to provide feedback to their employees compared to British counterparts due to the need to save face and to maintain a good relationship with employees (Wakabayashi et al., 2001). Thus, Taiwanese managers prefer to keep the reward range narrow and recognise and reward best performers. However, they also encourage the worst achievers to improve current job performance rather than applying control techniques of formal and systematic performance appraisal as British firms tend to do (Easterby-Smith et al., 1995; Cully et al., 1999; Guest and Conway, 1999).

\section{Management promotion and reward}

There are noticeable cross-cultural differences between Taiwan and the UK in managers' criteria for promotion and reward (Von Glinow et al., 1999). Previous researchers pointed out that there is high level of collectivism in Taiwan compared to the UK (Hofstede, 1980, 1993, 1997; Yeh, 1987). A good manager in Taiwan needs to generate cooperation among employees and show loyalty to the organisation. Seniority is also more important in Taiwan than in the UK (Von Glinow et al., 1999). By contrast, British companies tend to use 'hard' performance criteria such as 'bottom line delivery'; experience in more than 
one business area as well as another country; functional experience; and overall performance record as a yard stick (Easterby-Smith et al., 1995).

\section{Flexible working}

Most Taiwanese companies provide a stable and permanent job for workers. According to Executive Yuan’s (2003) statistics, only 1.2 per cent of total labour force consists of

part-time workers among Taiwanese firms. This is due at least in part to the influence of Confucius values such as ‘long term orientation’ (Hofstede and Bond, 1988). By contrast, in Britain, nearly quarter of the workforce consists of part-time workers (OECD, 2003) and about $64 \%$ of the British workforce worked on a part time basis in 2004 (Kersley et al., 2005).

\section{Organisational communication}

Taiwanese managers are concerned with the risk of losing face (Redding, 1990). As a result, Taiwanese firms focus less on goal-setting and open-communication methods to disseminate their business mission and strategy (Wu, 2004). Communication between employees and managers is kept to minimum and up-ward feedback is non-existent. By contrast, British firms tend to conduct formal communication in their organisations through regular meetings between senior management and all employees (Cully et al., 1999; Kersley et al., 2005). In addition, British firms tend to transmit their corporate mission statements, credos, and visions as a formal tool of management (Ferner and Varul, 1999, 2000; Kersley et al., 2005). 


\section{Participatory management and industrial relations}

Influenced by Confucian values of collectivism and harmony (Hofstede and Bond, 1988), participatory management tools such as quality control circles, labour-management committee and work councils are widely used in Taiwanese firms (e.g. Huang, 1997; Wakabayashi et al., 2001; Zhu et al., 2000; Zhu, 2003). In comparison, British firms use less participatory management tools, but tend to have an elaborate system of control through budget setting and monitoring systems that are oriented to short-term financial performance (Coates et al., 1992; Ferner and Quinntanilla, 1998; Ferner and Varul, 1999, 2000).

The role of trade unions in Taiwan is limited to performing administration functions such as arranging communication programmes for managers and employees and organising annual meetings for all employees within the companies (Zhu et al., 2000; Zhu, 2003). The unions are not part of the enterprises’ decision-making processes (Zhu, 1995; Zhu et al., 2000) and in practice they will not exercise the right of collective bargaining. In the UK, unions historically have had a more adversarial role and collective bargaining is part of their raison d'etre.

Insert Table 1 about here

On the basis of the above comparisons, we aim to explore the following questions: Which home country HRM strategies and practices are more likely to be transferred by Taiwanese MNCs in the UK? Which host country HRM strategies and practices are more likely to be adopted by Taiwanese MNCs in the UK? Which type of HRM 
strategies and practices are chosen by Taiwanese MNCs under the pressure from home and host country effect?

\section{Method}

We approached all 100 subsidiaries of Taiwanese MNCs in the UK via the Taiwan Foreign Trade Centre in London and FAME database. A questionnaire was sent to all personnel/HR managers of Taiwanese subsidiaries from the FAME database. Items of the questionnaire were developed from the "Price Waterhouse”, and "Cranfield" Survey (Brewster and Hegewisch, 1994). The researchers developed specific items, such as HRM practices used by Taiwanese MNCs. The data was collected between June 2004 and December 2004. For the companies that did not return the required information, follow-up telephone calls were made and follow-up letters were sent. Of the 100 questionnaires mailed, 45 usable responses were received after the initial mailing, and additional 36 usable responses were received after the follow-up procedures. The total of usable response was 81 .

\section{Sample}

Respondents were asked to rank HRM practices and the key factors affecting those strategies and business practices. As shown in Table 2, $98 \%$ of the subsidiaries in which respondents were employed were small and medium sized. $84 \%$ of the subsidiaries were based in the IT and electronic component industry. 89\% of the subsidiaries were 
greenfield companies. 83\% of the staff of the respondent subsidiaries were local-hired. $54 \%$ of the respondent subsidiaries' final market(s) were the in UK, $19 \%$ were in Europe, and $27 \%$ were worldwide.

Insert Table 2 about here

\section{Findings}

\section{HRM and strategic integration}

Only 13\% reported that HR managers in the subsidiaries have been consulted in terms of HRM strategic development. The majority of HR managers (61\%) reported that headquarters (HQ) do not consult the subsidiaries on issues regarding HRM development and business strategy. Further, 63\% of the respondents reported that the HQ in Taiwan has the major decision-making authority in relation to decisions concerning workforce expansion and/or reduction. This indicates that when it comes to HR strategies such as business strategy and work force expansion or reduction, the decision-making power is mainly located in the HQ in Taiwan. The subsidiary HR department is largely responsible for day-to-day HR policies and practices (see table 4).

Insert Table 3 about here 


\section{Recruitment methods}

Taiwanese MNCs in the UK use a range of recruitment methods for attracting candidates (see table 5). When it comes to managerial and professional— technical and scientific— recruitment, both of home country practices (quanxi-connection) and host country practices especially advertise externally and recruitment agencies are extensively used. Recruitment methods, such as to advertise internally and use of consultants, are seldom used for managerial, professional and technical positions. For clerical and manual recruitment, both of home country practices such as quanxi and host country practices such as use of recruitment agencies, are used more frequently. Advertising externally is used for all positions.

Insert Table 4 about here

\section{Selection, Training and Development}

Interview panels, application forms, and references are the main selection techniques used by responding subsidiaries (see table 6). Graphology, assessment centre, psychometric testing, group selection methods, bio data, aptitude test, and competencybased interviews were used less frequently. However, medium-sized and large Taiwanese subsidiaries in the UK appear to use psychometric testing more frequently than smallsized ones.

Insert Table 5 about here 
On-the-job training methods appear to be used most frequently by the responding Taiwanese subsidiaries in the UK. The UK is the dominant training location for professional and technical positions. At the managerial level, HQ in Taiwan is the main training location.

\section{Pay and Appraisals}

Individual performance is a commonly used criterion (79\%) for pay systems by the responding Taiwanese subsidiaries in the UK. HQ’s performance measure to assess individual performance is used by $40 \%$ of respondents. Only $15 \%$ of respondents reported the use of group and team performance. Further, data shows that $63 \%$ of managers, $63 \%$ of professionals, $62 \%$ of sales staff, and $61 \%$ of technical and scientific staff are frequently "formally" appraised on an individual basis, in contrast to clerical and manual staff. Most subsidiaries (42\%) assess employees’ performance on an annual basis and around one-third (30\%) do not have a formal performance appraisal system.

The data indicates that the main purposes of performance appraisal were in setting personal objectives and reviewing progress over the past objectives (58\%), giving feedback to employees on their performance (40\%), and allocating rewards (32\%). Only $26 \%$ of the responding subsidiaries linked their performance appraisal results to pay. Hence, pay for performance is not widely used by all Taiwanese MNCs in the UK due to the need to protect face and establish good relationships with subordinates (Wu, 2004). 


\section{Management promotion/reward practices}

The survey shows that a range of criteria for management promotion have been used to varying degrees by the responding Taiwanese subsidiaries in the UK for promoting and rewarding management positions. 'Individual performance’ seems to be used the most frequently. Other criteria, such as 'group performance', 'seniority', and 'loyalty' are seldom used. This also indicates a more westernised approach on this aspect of HRM.

\section{Flexible working practice}

Taiwanese MNCs tend to recruit permanent employees for their operations. The overwhelming majority of subsidiaries—93\%, 90\% and $86 \%$-did not use part time, temporary, and fixed term employees respectively. This indicates that Taiwanese subsidiaries in the UK appear to adopt home-country practice with regard to flexible working practice.

\section{Organisation communication practices}

More than $40 \%$ of employees were not formally briefed about business strategy and financial performance. This is due to the fact that Taiwanese MNCs tend to place less emphasis on communicating business strategy and on financial performance communication (e.g. Wakabayashi et al., 2001; Wu, 2004) (table 7).

Insert Table 6 about here 


\section{Participatory management tools}

A range of participatory management tools were used to varying degrees. Problemsolving and continuous improvement groups (44\%) and quality circles (28\%) have been widely used. Joint consultative committee and work councils (3.7\%) are rarely used and only one subsidiary recognised a trade union.

\section{Discussions and Conclusions}

The results of this study suggest that subsidiaries of MNCs from emerging economies adopt a blend of home and host country HRM practices. As depicted in figure 1 both push and pull factors are at play. First, the push force from the HR in Taiwan is clearly evident in relation to strategic issues such as workforce expansion and reduction. Second, the pull force for conformity to host country practices is evident in HRM implementation processes and some HRM policies and practices such as pay and appraisal and recruitment methods. Third, as a result of both push and pull forces, evidence suggests that most HRM practices are a melange of home and host country practices. Our results indicate that in contrast, the widely reported single HRM approach adopted by developed MNCs such as Japanese MNCs in USA (e.g. Beechler and Yang, 1994) and US MNCs in China (e.g., Farley et al., 2004) and German MNCs in the UK (Ferner and Varul, 1999) and US MNCs in the UK (Ferner et al., 2005), Taiwanese MNCs tend to adopt a blend of home and host country practices. 


\section{Home Country practices}

The home country effect is significant both in strategic and some functional areas of HRM practices. It is clear that in terms of primary HRM responsibility issue, the main strategic decision-making remains with HQ in Taiwan especially on issues such as workforce expansions and redundancy. Thus, one could conclude that HQ in Taiwan adopts a 'top down' approach in managing its relationship with the local subsidiary by not consulting local subsidiary with regard to business objectives.

Moreover, overseas Taiwanese subsidiaries tend to comply with home country practices especially in the area of types of employment, recruitment and training in managerial and technical jobs across their subsidiaries. It would be interesting to understand the reasons why these particular practices are strongly influenced by home country practices. Practices that are underpinned by Taiwanese cultural values such as protection of face and Confucianism are generally adopted by Taiwanese subsidiaries in the UK. Exceptions here include the weak emphasis on seniority and use of individualized performance measures.

\section{Host Country practices}

A host country effect was particularly evident in relation to a high proportion of localhired employees (83\%), the wide use of recruitment agencies, individual performance pay, and promotion and reward based on individual performance. Certainly one might expect that due to strong pressure from the host country to conform to local institutional environments, the subsidiaries were more influential in relation to decisions on pay and benefits, recruitment and selection, training and development, industrial relations, and 
health and safety. These extra local operational pressures strongly influence local managers to use host country practices. Indeed, institutional influences from the host country such as the host country legal environment and utilization of local resources such as customers and employees are the priority for Taiwanese MNCs in the UK. Hence, UK practices such as recruitment agencies are commonly adopted by Taiwanese MNCs. This suggests that due to the tight budget and cost control by the HQ in Taiwan and complete vacancy fill-in task, a HR manager tends to be sensitive to minimise costs in recruiting suitable employees for operational needs. Further, our results suggest that under the influence of a highly individualised society, individual performance is widely used for rewarding and promoting employees.

\section{A modification style}

The behaviours of MNCs in host countries may be a synthesis or 'hybrid' in which host country norms mediate the influence of the home country 'blueprint' (Innes and Morris, 1995:30). Examples here include the measure of individual performance, where both home country and host country effects were reported. Our results suggest that both ‘individual performance/output' and adoption of 'HQ's performance measure' were commonly adopted by responding Taiwanese subsidiaries in the UK. An implication of choice of a modified style is that the influence of national culture, i.e. 'the middle way' approach'.

Insert Figure 1 about here 
The contribution of this paper is as follows. First, we have identified HRM practices used by emerging economy MNCs in an advanced economy. Second, our results suggest that MNCs from emerging economies behave differently from MNCs from developed countries such as Japan, US and Western European countries. Past research shows that MNCs from advanced economies such as Japanese MNCs in the UK tend to transplant the ideas and practices of so-called excellent human resource management systems, for instance, Komatsu and Mazak, from their own parent companies (Gleave and Oliver, 1990). American MNCs in the UK also wholly transfer their home country practices such as union avoidance strategy to the UK subsidiaries (e.g. Hamill, 1984). However, Taiwanese MNCs deliberately adopt a varied HR approach to operate in an advanced economy as a result of dual pressures of home and host country effect. Consequently, apart from strategic issues wholly made by HQ in Taiwan, other HR practices either adapt to local practices or use a hybrid style.

While the current study was centred on Taiwanese MNCs operating in the UK, future studies of HRM strategies and practices could be extended to HQ in Taiwan and other Taiwanese subsidiaries both in Europe and the United States. Moreover, more research about how multiple HRM strategies and practices interrelate and why they are chosen simultaneously by MNCs from emerging economies in advanced countries may require in-depth case study interviews, longitudinal research, document studies, and observation studies in order to observe complex decision-making process between HQ and overseas subsidiaries. 


\section{References}

Almond, P., Edwards, T. and Clark, I. (2003) "Multinationals and Changing Business Systems in Europe: Towards the 'Shareholder Value' Model?", Industrial Relations Journal, 34(5): 430-45.

Awasthi, V.N., Chow, C.W. and Wu, A. (2001) "Cross-Cultural Differences in the Behavioural Consequences of Imposing Performance Evaluation and Reward Systems: An Experimental Investigation", The International Journal of Accounting, 36: 291-309.

Bae, J. Shyh-jer Chen and Lawler, J.J. (1998) "Variations in Human Resource Management in Asian Countries: MNC Home-Country and Host-Country Effects", The international Journal of Human Resource Management, 9(4): 653-70.

Beechler, S. and Yang, J.Z. (1994) "The Transfer of Japanese-Style Management to American Subsidiaries: Contingencies, Constraints, and Competencies", Journal of International Business Studies, 25: 467-91.

Chen, S., Ko, J. \& Lawler, J. (2003) "Changing Patterns of Industrial Relations in Taiwan", Industrial Relations, 42(3): 315-44.

Chow, C.W., Harrison, G.L., McKinnon, J.L. and Wu, A. (2000) "The Organizational, Culture of Public Accounting Firms: Evidence from Taiwanese Local \& US Affiliated Firms", Accounting, Organizations \& Society, 27(4/5): 347-61.

Chow, C.W., Shields, M. and Wu, A. (1999) "The Importance of National Culture in the Design of Preference for Management Controls for Multi-National Operations", Accounting, Organizations and Society, 24: 441-61.

CIPD (2004) Recruitment, Retention and Turnover: A Survey of the UK and Ireland, CIPD, London.

Coates, J., Davis, E., Emmanuel, C., Longden, S. \& Stacey, R. 1992, "Multinational Companies Performance Measurement Systems: International Perspectives", Management Accounting Research, vol. 3, pp. 133-150.

Cully, M. (1999) Britain at Work: As Depicted by the 1998 Workplace Employee Relations Survey, Routledge, London.

Easterby-Smith, M., Malina, D. and Yuan, L. (1995) "How Culture Sensitive is HRM? A Comparative Analysis of Practice in Chinese and UK Companies", International Journal of Human Resource Management, 6(5): 31-60.

Edwards, T. (1998) Multinational Companies and the Diffusion of Employment Practices: A Review of the Literature, IRRU, Warwick.

Edward, T. and Ferner, A. (2004) "Multinationals, Reverse Diffusion and National Business Systems", Management International Review, 24(1): 51-81.

Executive Yuan Economic Development Committee (2003) Monthly Report on Employment Conditions, Executive Yuan, Taiwan.

FAME. (2004) Financial Analysis Made Easy.

Farley, J.U., Hoenig, S. and Yang, J.Z. (2004) "Key Factors Influencing HRM Practices of Overseas Subsidiaries in China's Transition Economy", International Journal of Human Resource Management, 15(4-5): 688-704. 
Faulkner, D., Pitkethly, R. and Child, J. (2002) "International Mergers and Acquisitions in the UK 1985-94: A Comparison of National HRM Practices", International Journal of Human Resource Management, 13(1):106-22.

Ferner, A. (1997) "Country of Origin Effects and HRM in Multinational Companies", Human Resource Management Journal, 7(1): 19-37.

Ferner, A., Almond, P. and Colling, T. (2005) "Institutional Theory and the CrossNational Transfer of Employment Policy: The Case of 'Workforce Diversity' in US Multinationals", Journal of International Business Studies, 36(3): 304-21.

Ferner, A. and Quintainilla, J. (1998) "Multinationals, National Business Systems and HRM: the Enduring of National Identity or A Process of 'Anglo-Saxonization"', The International Journal of Human Resource Management, 9(4): 710-31.

Ferner, A. and Varul, M.Z. (1999) The German Way: German Multinationals and Human Resource Management, Anglo-German Foundation, London.

Gamble, J. (2003) "Transferring Human Resource Practices from the United Kingdom to China: the Limits and Potential for Convergence", The International Journal of Human Resource Management, 14(3): 369-87.

Gleave, S. and Oliver, N. (1990) "Human Resources Management in Japanese Manufacturing Companies in the UK: 5 Case Studies", Journal of General Management, 16(1): 54-68.

Guest, D. (2001) "HRM in the UK" in Human Resource Management: A Critical Text, In J. Storey $\left(2^{\text {nd }}\right)$ (ed.), Thomson Learning, London.

Guest, D. and Conway, N. (1999) "Peering into the Black Hole: The Downside of the New Employment Relations in the UK", British Journal of Industrial Relations, 37(3): 367-89.

Guest, D. and Hoque, K. (1996) "National Ownership and HR Practices in UK Greenfield Sites", Human Resource Management Journal, 6(4): 50-75.

Hamill, J. (1984) "Labour Relations Decision Making Within Multinational Corporations", Industrial Relations Journal, 15(2): 1-4.

Hempel, P.S. and Chang, C-Y. D. (2002) "Reconciling Traditional Chinese Management with High-Tech Taiwan", Human Resource Management Journal, 12(1): 77-95.

Hillman, A. \& Wan, W.P. 2005, "The Determinants of MNE Subsidiaries' Political Strategies: Evidence of Insitutional Duality", Journal Of International Business Studies, vol. 36, no. 3, pp. 322-340.

Hofstede, G. (1980) Culture's Consequences: International Differences in Work-Relation Beliefs, Beverly Hills, CA: Sage.

Hofstede, G. (1993) "Cultural Constraints in Management Theories", Academy of Management Review, 7(1): 81-95.

Hofstede, G. (1997) "The Business of International Business is Culture" In Vernoinwortzel, H. and Van Ruysseveldt, J. (ed.) International Human Resource Management, Sage, London.

Hofstede, G., and Bond, M.H. (1988) "The Confucius Connection: From Cultural Roots to Economic Growth", Organizational Dynamics, 14: 4-21. 
Hsu, Y-R. and Leat, M. (2000) "A Study of HRM and Recruitment and Selection Policies and Practices in Taiwan", The International Journal of Human Resource Management, 11(2): 413-35.

Huang, T. (1997) "The Effect of Participate Management on Organizational Performance: The Case of Taiwan", The International Journal of Human Resource Management, 8(5): 667-80.

Huang, T. (2000) "Human Resource Management Practices at Subsidiaries of Multinational Corporations and Local Firms in Taiwan", International Journal of Selection and Assessment, 8(1): 22-8.

Innes, E. and Morris, J. (1995) "Multinational Corporations and Employee Relations: Continuity and Change in a Mature Industrial Region", Employee Relations, 17(6): 30-50.

Kersley, B., Alpin, C., Forth, J., Bryson, A., Bewley, H. and Gill, D. (2005) Inside the Workplace: First Findings from the 2004 Workplace Employment Relations Survey (WERS 2004), DTI, London.

Liu, X., Buck, T.W. and Shu, C. (2005) "Chinese Economic Development, the Next Stage: Outward FDI?” International Business Review, 14(1): 97-115.

Muller, M. (1998) "Human Resource and Industrial Relations Practices of UK and US Multinationals in Germany", The International Journal of Human Resource Management, 9(4): 732-49.

OECD 2003, OECD Issues 2003 Employment Outlook, OECD, Geneva.

Redding, S.G. (1990) The Spirit of Capitalism, Walter de Gruyter, New York.

Rosenzweig, P.M. and Nohria, N. (1994) "Influences on Human Resource Management Practices in Multinational Corporations", Journal of International Business Studies, 25: 229-51.

Tayeb, M. 1998, "Transfer of HRM Practices Across Cultures: An American Company in Scotland", The International Journal of Human Resource Management, 9(2): 332-58.

Taylor, S., Beechler, S. and Napier, N. (1996) "Toward an Integrative Model of Strategic International Human Resource Management", Academy of Management Review, 21(4): 959-85.

Ulgado, F.M., Yu, Chow-Ming and Negandi, A.R. (1994) "Multinational Enterprises from Asian Emerging Countries", Management International Business Review, 3(2): 279-301.

United Nations. (2003) UN World Investment Report.

Von Glinow, M.A., Huo, Y. and Lowe, P. K. (1999) "Leadership Across the Pacific Ocean: A Trinational Comparison", International Business Review, 8: 1-15.

Wakayashi, M., Chen, Z. and Kondo, M. (2001) "Comparative Managerial Skills: A Study on Asian-Styles of Management Based on Managers From Ten Different Area/Nations", Forum of International Development Studies, 1-20.

Wu, P. (2004), "HRM in Taiwan". In P.S. Budwar (ed.) Management Human Resources in Asia-Pacific, Routledge, London.

Yeh, R. (1987) "Management Practices of Taiwanese Firms: As Compared to Those of American and Japanese Subsidiaries in Taiwan", Asia Pacific Journal of Management, 8(1): $1-14$.

Zhu, Y. (2003) "The Post Asian Financial Crisis: Changes in Human Resource Management in Taiwanese Enterprises", Asia Pacific Business Review, 9(4): 148-64. 
Zhu, Y., Chen, I. And Warner, M. (2000), "HRM in Taiwan: An Empirical Case Study", Human Resource Management Journal, 10(4): 33-44. 
Table 1 Comparisons in HRM between Taiwan and UK

\begin{tabular}{|c|c|c|c|}
\hline Items & Taiwan & UK Subsidiary & UK \\
\hline Recruitment & $\begin{array}{l}\text { - 'Recruitment agencies } \\
\text { 'and ‘executive search } \\
\text { consultants' are less } \\
\text { commonly used for } \\
\text { managerial and } \\
\text { professional vacancies } \\
\text { - Spend minimum money in } \\
\text { selection }\end{array}$ & $\begin{array}{l}\text { - Managerial level: } \\
\text { Others (sent from HQ } \\
\text { in Taiwan, quanxi, } \\
\text { friends), advertise } \\
\text { externally } \\
\text { - } \\
\text { Professional/technical } \\
\text { level: quanxi, others } \\
\text { (sent from HQ in } \\
\text { Taiwan), advertise } \\
\text { externally } \\
\text { Clerical/Manual } \\
\text { levels: advertise } \\
\text { externally, word of } \\
\text { mouth, use of } \\
\text { recruitment agencies }\end{array}$ & $\begin{array}{l}\text { - } \quad \text { 'Recruitment agencies ‘and } \\
\text { 'executive search } \\
\text { consultants' are commonly } \\
\text { used for managerial and } \\
\text { professional vacancies } \\
\text { - Spend more money in } \\
\text { selecting the right employee }\end{array}$ \\
\hline Selection & $\begin{array}{l}\text { - 'Panel interview', 'aptitude } \\
\text { tests', ‘competency-based } \\
\text { interviews' and application } \\
\text { forms' are less commonly } \\
\text { used for all levels }\end{array}$ & $\begin{array}{l}\text { All levels: application } \\
\text { form, individual } \\
\text { interview and } \\
\text { interview panel }\end{array}$ & $\begin{array}{l}\text { - 'Panel interview', 'aptitude } \\
\text { tests', ‘competency-based } \\
\text { interviews' and 'application } \\
\text { forms' are commonly used } \\
\text { for all levels }\end{array}$ \\
\hline Training & $\begin{array}{l}\text { - Low in conducting training } \\
\text { needs systematically } \\
\text { - On-the-job training }\end{array}$ & $\begin{array}{l}\text { - } \\
\text { - }\end{array}$ & $\begin{array}{l}\text { - Low in conducting training } \\
\text { needs systematically } \\
\text { - Off-the-job training (e.g. } \\
\text { courses) }\end{array}$ \\
\hline Pay and Benefits & $\begin{array}{l}\text { - High in egalitarianism and } \\
\text { Low in pay differentials }\end{array}$ & $\begin{array}{ll}\text { - } & \text { Individual } \\
& \text { performance }\end{array}$ & $\begin{array}{l}\text { - Low in egalitarianism and } \\
\text { High in pay differentials }\end{array}$ \\
\hline
\end{tabular}




\begin{tabular}{|c|c|c|c|}
\hline & $\begin{array}{l}\text { between those at the top } \\
\text { and those at the bottom } \\
\text { - } \quad \text { PFP is less commonly used }\end{array}$ & $\begin{array}{l}\text { system } \\
\text { experience }\end{array}$ & $\begin{array}{l}\text { between those at the top and } \\
\text { those at the bottom } \\
\text { - } \quad \text { PFP is commonly used }\end{array}$ \\
\hline $\begin{array}{l}\text { Performance } \\
\text { Appraisal }\end{array}$ & $\begin{array}{l}\text { - Frequency: less likely used } \\
\text { - } \quad \begin{array}{l}\text { Measure of performance: } \\
\text { emphasis on group } \\
\text { performance }\end{array} \\
\text { - } \begin{array}{l}\text { Purpose: reluctant to } \\
\text { provide feedback }\end{array}\end{array}$ & $\begin{array}{l}\text { - Frequency: More than } \\
\text { 1/3 has performance } \\
\text { appraisal systems on } \\
\text { annual basis } \\
\text { - Measure of } \\
\text { performance: } \\
\text { Individual } \\
\text { performance/output } \\
\text { and adoption of HQ’s } \\
\text { standard } \\
\text { Purpose: set personal } \\
\text { objectives and review } \\
\text { progress again past } \\
\text { objects, give feedback } \\
\text { to employee on their } \\
\text { performance }\end{array}$ & $\begin{array}{l}\text { - Frequency: formal and } \\
\text { systematic used } \\
\text { - Measure of performance: } \\
\text { individual performance } \\
\text { - } \quad \text { Purpose: provide feedback }\end{array}$ \\
\hline $\begin{array}{l}\text { Management } \\
\text { appointments } \\
\text { criteria }\end{array}$ & $\begin{array}{l}\text { - Soft criteria such as } \\
\text { 'emphasis on generating } \\
\text { participation and } \\
\text { involvement', 'a } \\
\text { cooperative group action', } \\
\text { 'loyalty' }\end{array}$ & $\begin{array}{ll}\text { - } & \text { Individual } \\
\text { performance }\end{array}$ & $\begin{array}{l}\text { - Hard criteria such as 'bottom } \\
\text { line delivery', 'more than } \\
\text { one business area', } \\
\text { 'experience in another } \\
\text { country' }\end{array}$ \\
\hline Flexible working & $\begin{array}{l}\text { - } \quad \text { Part-time work is less } \\
\text { commonly used }\end{array}$ & $\begin{array}{l}\text { - Less than } 1 \text { percent } \\
\text { part time, temporary, } \\
\text { and fixed-term }\end{array}$ & $\begin{array}{l}\text { - Part-time work is commonly } \\
\text { used }\end{array}$ \\
\hline
\end{tabular}




\begin{tabular}{|c|c|c|c|}
\hline & & employees & \\
\hline $\begin{array}{l}\text { Organisational } \\
\text { communication }\end{array}$ & $\begin{array}{l}\text { - Open-communication } \\
\text { methods is less commonly } \\
\text { used } \\
\text { - Less likely to transmit } \\
\text { business mission }\end{array}$ & $\begin{array}{l}\text { - No formal methods } \\
\text { for all levels } \\
\text { - Both of strategy and } \\
\text { financial performance } \\
\text { are seldom transmitted } \\
\text { to employees }\end{array}$ & $\begin{array}{l}\text { - Open-communication } \\
\text { methods are commonly used } \\
\text { such as ‘systematic use of } \\
\text { the management chain', } \\
\text { 'regular newsletter', 'regular } \\
\text { meeting', 'suggestion } \\
\text { schemes' } \\
\text { - More likely to transmit } \\
\text { business mission and } \\
\text { financial performance }\end{array}$ \\
\hline $\begin{array}{l}\text { Participatory } \\
\text { management } \\
\text { and Industrial } \\
\text { relations }\end{array}$ & $\begin{array}{l}\text { Quality circles is } \\
\text { commonly used } \\
\text { - Less likely to exercise } \\
\text { collective bargaining }\end{array}$ & $\begin{array}{l}\text { - } \text { Quality circles, } \\
\text { problem-solving } \\
\text { groups/continuous } \\
\text { improvement groups } \\
\text { are widely used } \\
\text { - } \text { No trade union (only } 1 \\
\text { Taiwanese subsidiary } \\
\text { organises but not for } \\
\text { collective bargaining) }\end{array}$ & $\begin{array}{l}\text { Less employee participation } \\
\text { in monitoring quality } \\
\text { - } \begin{array}{l}\text { More likely to exercise } \\
\text { collective bargaining }\end{array}\end{array}$ \\
\hline
\end{tabular}

Source: author and survey findings. 
Table 2 Major characteristics of the responding companies

\begin{tabular}{|l|l|c|}
\hline Items & Grouping & $\%$ \\
\hline Industry sector & IT and Electronic component & 84 \\
& Financial services & 7 \\
& Transportation & 5 \\
& Others & 4 \\
\hline Employee No. & Small (1-49) & 83 \\
& Medium (50-249) & 14 \\
& Large (>250) & 3 \\
\hline Entry mode & Greenfield & 89 \\
& Brownfield & 11 \\
\hline Employee breakdowns & Local-hired & 83 \\
& Expatriate & 17 \\
\cline { 2 - 3 } & Male & 61 \\
& Female & 39 \\
\hline Final Market(s) & UK & 54 \\
& Europe & 19 \\
\hline Decision-making authority ${ }^{1}$ & World-wide & 27 \\
\hline (multiple choices) & MD/GM in the UK subsidiary & 64 \\
& Owner of the whole group & 49 \\
& Director and GM in HQ & 36 \\
\hline Professional Qualifications for HR & Family member of the whole group & 1 \\
\hline manager in the UK subsidiary & Other & 9 \\
\hline \multirow{2}{*}{ Notes } & Diploma in Personnel & \\
\hline & Management(including CIPD membership) & 6 \\
\hline & Other(e.g. accounting, teaching etc.) & 94 \\
\hline
\end{tabular}

1. There are multiple choices for decision-making authority.

2. Other includes regional HQ in other countries. 
Table 3 Primary responsibilities for HRM functions/activities

\begin{tabular}{|l|l|l|l|l|}
\hline Functions/activities & $(1) \%$ & $(2) \%$ & $(3) \%$ & $(4) \%$ \\
\hline Pay and benefits & 36 & 5 & 51 & 9 \\
\hline $\begin{array}{l}\text { Recruitment and } \\
\text { selection }\end{array}$ & 28 & 10 & 52 & 10 \\
\hline $\begin{array}{l}\text { Training and } \\
\text { development }\end{array}$ & 30 & 11 & 49 & 10 \\
\hline Industrial Relations & 30 & 10 & 51 & 10 \\
\hline Health and safety & 28 & 10 & 51 & 11 \\
\hline Workforce/expansion & 63 & 7 & 22 & 7 \\
\hline Notes & & \multicolumn{2}{c|}{$n=81$}
\end{tabular}

(1) HQ in Taiwan, (2) Regional HQ central personnel, (3) Subsidiary service dept./division, (4) HR dept. in subsidiaries. 
Table 4 Recruitment methods

\begin{tabular}{|c|c|c|c|c|c|c|c|c|}
\hline $\begin{array}{l}\text { Recruitment } \\
\text { Methods }\end{array}$ & $\begin{array}{l}\text { Managerial } \\
\text { Frequency }\end{array}$ & $\%$ & $\begin{array}{l}\text { Profession } \\
\text { Scientific } \\
\text { Frequency }\end{array}$ & $\begin{array}{l}\text { l/Technical/ } \\
\%\end{array}$ & $\begin{array}{l}\text { Clerical } \\
\text { Frequency }\end{array}$ & $\%$ & \begin{tabular}{|l} 
Manual \\
Frequency
\end{tabular} & $\%$ \\
\hline $\begin{array}{l}\text { From amongst } \\
\text { current } \\
\text { employees }\end{array}$ & 20 & 25 & 5 & 6 & 8 & 10 & 6 & 7 \\
\hline $\begin{array}{l}\text { Advertise } \\
\text { internally }\end{array}$ & 2 & 3 & 6 & 7 & 12 & 15 & 7 & 9 \\
\hline $\begin{array}{l}\text { Advertise } \\
\text { externally }\end{array}$ & 45 & 56 & 52 & 64 & 46 & 57 & 43 & 53 \\
\hline Word of mouth & 27 & 33 & 33 & 41 & 45 & 56 & 43 & 53 \\
\hline $\begin{array}{ll}\text { Use } & \text { of } \\
\text { recruitment } & \\
\text { agencies } & \end{array}$ & 38 & 47 & 43 & 53 & 40 & 49 & 38 & 47 \\
\hline $\begin{array}{l}\text { Use of } \\
\text { search/selection } \\
\text { consultants }\end{array}$ & 9 & 11 & 7 & 9 & 3 & 4 & 2 & 3 \\
\hline Job centre & 10 & 12 & 13 & 16 & 19 & 24 & 22 & 27 \\
\hline Apprentices & 1 & 1 & 4 & 5 & 1 & 1 & 4 & 5 \\
\hline $\begin{array}{l}\text { Quanxi(connect } \\
\text { ion) }\end{array}$ & 49 & 61 & 49 & 61 & 49 & 61 & 49 & 61 \\
\hline Others* & 10 & 12 & 10 & 12 & 10 & 12 & 10 & 12 \\
\hline
\end{tabular}

*Other include sent from HQ. 
Table 5 Selection techniques

\begin{tabular}{|l|l|l|l|l|l|}
\hline $\begin{array}{l}\text { Selection } \\
\text { techniques }\end{array}$ & $\begin{array}{l}\text { Always } \\
\%\end{array}$ & $\begin{array}{l}\text { Often } \\
\%\end{array}$ & $\begin{array}{l}\text { Sometimes } \\
\%\end{array}$ & $\begin{array}{l}\text { Seldom } \\
\%\end{array}$ & $\begin{array}{l}\text { Never } \\
\%\end{array}$ \\
\hline $\begin{array}{l}\text { Application } \\
\text { form }\end{array}$ & 79 & 5 & 6 & 0 & 10 \\
\hline $\begin{array}{l}\text { Interview } \\
\text { panel }\end{array}$ & 88 & 7 & 1 & 1 & 3 \\
\hline Bio data & 5 & 1 & 7 & 0 & 86 \\
\hline $\begin{array}{l}\text { Psychometric } \\
\text { testing }\end{array}$ & 1 & 3 & 0 & 9 & 88 \\
\hline Graphology & 0 & 0 & 3 & 5 & 93 \\
\hline References & 26 & 7 & 9 & 4 & 54 \\
\hline Aptitude test & 3 & 3 & 5 & 9 & 82 \\
\hline $\begin{array}{l}\text { Assessment } \\
\text { centre }\end{array}$ & 0 & 5 & 1 & 5 & 89 \\
\hline $\begin{array}{l}\text { Group } \\
\text { selection } \\
\text { methods }\end{array}$ & 0 & 4 & 4 & 6 & 86 \\
\hline $\begin{array}{l}\text { Competency- } \\
\text { based } \\
\text { interviews }\end{array}$ & 5 & 9 & 1 & 4 & 82 \\
\hline
\end{tabular}


Table 6 Communication Methods

\begin{tabular}{|c|c|c|c|c|c|c|c|c|c|}
\hline $\begin{array}{l}\text { Communicatio } \\
\mathrm{n} \text { Method }\end{array}$ & $\begin{array}{l}\text { Always } \\
\text { Frequency }\end{array}$ & $\%$ & $\begin{array}{l}\text { Often } \\
\text { Frequency }\end{array}$ & $\%$ & $\begin{array}{l}\text { Sometimes } \\
\text { Frequency }\end{array}$ & & $\begin{array}{l}\text { Seldom } \\
\text { Frequency }\end{array}$ & $\begin{array}{l}\text { Never } \\
\text { Frequency }\end{array}$ & $\%$ \\
\hline $\begin{array}{l}\text { Systematic use } \\
\text { of management } \\
\text { chain }\end{array}$ & 6 & 7 & 7 & 39 & 3 & 4 & 3 & 62 & 77 \\
\hline $\begin{array}{l}\text { Through } \\
\text { regular } \\
\text { workforce } \\
\text { meetings }\end{array}$ & 19 & 24 & 9 & 11 & 2 & 3 & 4 & 47 & 58 \\
\hline $\begin{array}{l}\text { Through } \\
\text { quality circles }\end{array}$ & 5 & 6 & 2 & 3 & 2 & 3 & 3 & 69 & 85 \\
\hline $\begin{array}{l}\text { Through } \\
\text { suggestion box } \\
\text { (es) }\end{array}$ & 1 & 1 & 2 & 3 & 3 & 4 & 4 & 71 & 88 \\
\hline $\begin{array}{l}\text { Through } \\
\text { attitude survey }\end{array}$ & 2 & 3 & 2 & 3 & 2 & 3 & 2 & 73 & 90 \\
\hline $\begin{array}{l}\text { Newsletter to } \\
\text { all employees }\end{array}$ & 0 & 0 & 5 & 6 & 4 & 5 & 4 & 68 & 84 \\
\hline $\begin{array}{l}\text { Opinion } \\
\text { surveys }\end{array}$ & 0 & 0 & 6 & 7 & 0 & 0 & 1 & 74 & 91 \\
\hline $\begin{array}{l}\text { No formal } \\
\text { methods }\end{array}$ & 48 & 59 & 4 & 5 & 2 & 3 & 1 & 26 & 32 \\
\hline Other* & 8 & 10 & 3 & 4 & 0 & 0 & 1 & 69 & 85 \\
\hline
\end{tabular}

*Other includes face-to-face communication. 
Figure 1 Map of a Blending of Various HRM Approaches by Taiwanese MNCs at the subsidiary level

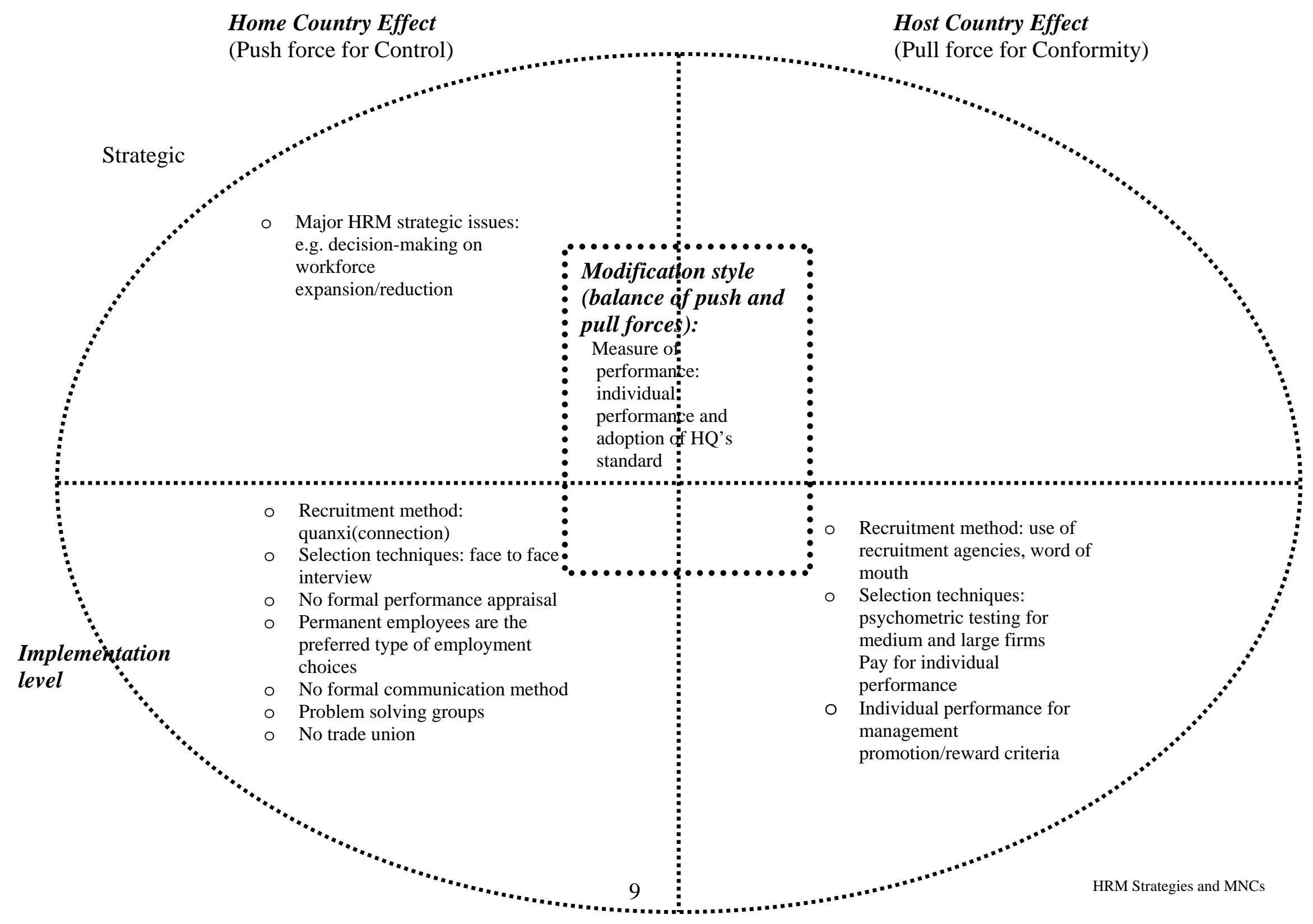


